УДК 347.9

\title{
ПРОБЛЕМЫ ВОЗМЕЩЕНИЯ МОРАЛЬНОГО ВРЕДА
}

\author{
Мицык Галина Юрьевна \\ к.юр.н., профессор \\ Московский гуманитарно-экономический университет
}

Аннотация: В статье на основе анализа действующего гражданского законодательства, материалов судебной практики, а также теоретических положений гражданского права, гражданско процессуального права, социологии и других наук, исследуются проблемы теории и практики возмещения морального вреда. Разработаны предложения по совершенствованию гражданского законодательства и практики его применения.

Ключевые слова: Компенсация морального вреда, денежная компенсация, физические и нравственные страдания, судебная практика, потерпевший, причинитель вреда.

\section{PROBLEMS OF COMPENSATION FOR MORAL HARM}

\section{Mitsyk Galina Yurievna}

Abstract: Based on the analysis of the current civil legislation, materials of judicial practice, as well as theoretical provisions of civil law, civil procedural law, sociology and other sciences, the problems of theory and practice of compensation for moral harm are investigated. Proposals have been developed to improve civil legislation and the practice of its application.

Key words: Compensation for non-pecuniary damage, monetary compensation, physical and mental suffering, judicial practice, the victim, the tortfeasor.

\section{1. Определение размера возмещения компенсации морального} вреда

Конституция РФ возводит право на жизнь, здоровье, честь и достоинство в ранг естественных и неотчуждаемых прав личности, что предполагает, в 


\section{ЧЕЛОВЕК И СОВРЕМЕННОЕ ОБЩЕСТВО В СОЦИАЛЬНОМ, ПРАВОВОМ, ЭКОНОМИЧЕСКОМ РАКУРСАХ}

частности, эффективную охрану и защиту этих прав. Важнейшей задачей правового государства должно быть обеспечение наиболее справедливого, быстрого и эффективного восстановления нарушенного права и (или) возмещение причиненного вреда. Российская Федерация, провозгласившая себя в ст. 1 Конституции РФ правовым государством, должна соответствовать этим критериям.

В качестве одного из видов вреда, который может быть причинен личности, в законодательстве выделяется моральный вред, т.е. страдания, вызванные различными неправомерными действиями (бездействием). Российское законодательство предусматривает возможность взыскания денежной компенсации за причиненный моральный вред.

Проведенный анализ и сравнение норм законодательства и судебной практики России, Англии, США и Германии в части компенсации морального вреда показывает большое сходство возникающих при применении этого правового института проблем. Прежде всего, обращает на себя внимание отсутствие детального законодательного регулирования института компенсации морального вреда не только в странах прецедентного права, где это предопределяется особенностями самой правовой системы этих государств, но и в стране статусного права Германии.

Законодательство нуждается в устранении имеющихся в нем пробелов в области возмещения морального вреда, поэтому в этой главе обращается внимание на проблемы определения размера компенсации морального вреда, компенсации при причинении имущественного ущерба; при защите чести, достоинства и деловой репутации граждан и юридических лиц, а также на имеющиеся проблемы в области вреда, причиненного незаконными действиями правоохранительных органов (дознания, полиции, прокуратуры).

Как уже отмечалось, в настоящее время законодатель фактически толкает судебную практику на формирование судебных прецедентов при определении размера морального вреда, подлежащего компенсации. В связи с отсутствием систематизации размера компенсируемого морального вреда по видам причиненного ущерба, судебная практика показывает, что ее средний размер колеблется от одной до нескольких десятков тысяч рублей [1,с. 15].

Критерии при определении размера компенсации морального вреда установлены в статьях 151 и 1101 ГК РФ: степень вины, степень физических и нравственных страданий, связанных с индивидуальными особенностями лица, 


\section{ЧЕЛОВЕК И СОВРЕМЕННОЕ ОБЩЕСТВО В СОЦИАЛЬНОМ, ПРАВОВОМ, ЭКОНОМИЧЕСКОМ РАКУРСАХ}

которому причинен вред, характер физических и нравственных страданий, оцениваемый с учетом фактических обстоятельств причинения морального вреда и индивидуальных особенностей потерпевшего, рассматриваемых с точки зрения разумности и справедливости и иные заслуживающие внимания обстоятельства.

Вышеуказанные критерии законодателем дополнено в ст.1083 ГК РФ еще двумя, общими для всех видов вреда: степень вины потерпевшего и имущественное положение причинителя вреда.

В Постановлении Пленума Верховного Суда РФ №10 от 20.12.1994 г. указывается на необходимость выяснения характера взаимоотношений сторон и возможность компенсации морального вреда по данному виду правоотношений. Пленум Верховного Суда РФ уделил внимание случаю, когда моральный вред нанесен до введения в действие законодательного акта в законную силу. Таким образом, предоставление права на компенсацию морального вреда в таких случаях невозможно, исключением являются противоправные действия ответчика, причинившие истцу нравственные или физические страдания до вступления в силу закона, который устанавливает ответственность, и они продолжаются после введения этого закона в действие, то моральный вред подлежит компенсации.

Для определения морального вреда при наличии имущественного вреда необходимо выяснить: какое имущество повреждено и его значение для потерпевшего с точки зрения важности для удовлетворения его потребностей; когда произошло повреждение имущества и при каких обстоятельствах и какие последствия в сфере имущественного и неимущественного вреда в том, что причинение неимущественного вреда может вызвать имущественный вред.

При грубой неосторожности потерпевшего, содействовавшей возникновению или размеру вреда, размер компенсации должен быть уменьшен (ст.1083 п.2 ГК РФ). Суд, с учетом имущественного положения причинителя вреда, может уменьшить размер компенсации морального вреда в соответствии со ст.1083 п.3 ГК РФ.

Все перечисленные критерии носят общий характер и предоставляют неограниченные возможности судье, который не связан ни верхним, ни нижним пределами присуждаемой денежной компенсации. 


\section{ЧЕЛОВЕК И СОВРЕМЕННОЕ ОБЩЕСТВО В СОЦИАЛЬНОМ, ПРАВОВОМ, ЭКОНОМИЧЕСКОМ РАКУРСАХ}

Считаем, что здесь нужно дополнительно учитывать индивидуальные особенности потерпевшего, но за основу брать некую среднюю величину, присущую нормальному человеку со здоровой психикой.

В законодательстве РФ возмещение морального вреда осуществляется в двух формах: нематериальной и денежной. Денежные средства - это своего рода «общий знаменатель» разрешения всех вопросов компенсации нарушения нематериальных благ. Именно денежная сумма побуждает в человеке определенные положительные эмоции для восстановления его психоэмоционального положения, существовавшего до нарушения права.

Однако на практике суд решает его следующим образом: если в деле есть доказательства того, что лицо после случившегося события обращалось за психологической, психиатрической помощью, был зафиксирован случай обращения за скорой медицинской помощью: гипертонический криз, сердечный приступ, инфаркт, инсульт и т.д. Причем, чем больше материального вреда здоровью было нанесено, тем более вреда было нанесено и психике человека. Организм человека работает таким образом, что возникновение нарушений (отклонений) в работе какого-либо одного органа в свою очередь повлечет отклонения (нарушения) в работе других органов. Поэтому если человек пережил в связи с каким-либо событием сильное душевное волнение, то это может впоследствии выразиться в нарушении сна, повышенном чувстве страха перед каким-либо объектом, нарушении нормальной работы сердечно-сосудистой системы, что затем повлечет и другие отклонения. Во всех случаях при рассмотрении в судах дел о компенсации морального вреда судьи при определении суммы, подлежащей взысканию с причинителя вреда, смотрят именно на те последствия, которые наступили для здоровья человека в функционировании других его органов.

Возникает вопрос, как выяснять размер причиненного ущерба при причинении вреда деловой репутации юридического лица, индивидуального предпринимателя, политического деятеля. Здесь необходимо рассмотреть те последствия, которые возникли в работе организации, а в отношении политического деятеля можно говорить о последствиях, выразившихся в резком падении его рейтинга или так же отразившихся на его здоровье потерпевшего.

Нематериальной формой компенсации морального вреда служит принесение прокурором от имени государства официального извинения реабилитированному за причиненный ему вред. Возложение этой обязанности 


\section{ЧЕЛОВЕК И СОВРЕМЕННОЕ ОБЩЕСТВО В СОЦИАЛЬНОМ, ПРАВОВОМ, ЭКОНОМИЧЕСКОМ РАКУРСАХ}

именно на прокурора обусловлено тем, что данный участник уголовного судопроизводства от имени государства осуществляет уголовное преследование, а также надзор за процессуальной деятельностью органов дознания и органов предварительного следствия (ч. 1 ст. 37 УПК РФ).

УПК РФ предусматривает обязательное сообщение средства массовой информации о реабилитации лица, если в них были распространены сведения о задержании, заключении его под стражу, временном отстранении его от должности, применении к нему принудительных мер медицинского характера, об осуждении и иных примененных к реабилитированному незаконных действиях. Данное правило касается как публикаций в печати, так и распространения сведений об уголовном преследовании лица по радио, телевидению или в любых иных средствах массовой информации. Информация о реабилитации лица сообщается по требованию реабилитированного (а в случае его смерти - по требованию его близких родственников или родственников) либо по письменному указанию суда, прокурора, следователя, дознавателя. Средства массовой информации обязаны сделать сообщение о реабилитации в течение 30 суток с момента поступления соответствующего требования или указания.

При отказе средства массовой информации в распространении сообщения о реабилитации реабилитированный может предъявить к нему иск с таким требованием на основании ч. 2 ст. 152 ГК РФ. Нематериальной формой возмещения морального вреда является также направление письменного сообщения о принятых решениях, оправдывающих гражданина, по месту его работы, учебы или месту жительства. Данная обязанность возложена на суд, прокурора, следователя, дознавателя, которые в случае поступления требования реабилитированного, а в случае его смерти - его близких родственников или родственников должны выполнить указанную обязанность в течение 14 суток.

При взыскании компенсации морального вреда конкретные обстоятельства, оцененные судом и повлиявшие на размер компенсации, должны указываться в судебном акте, которым взыскана такая компенсация.

Следует отметить, что при взыскании денежных сумм необходимо учитывать реальные возможности причинителя вреда. В любом случае принципы разумности и справедливости, названные в п. 2 ст. 1101 ГК РФ, являются важнейшими при определении судом размера компенсации морального вреда. Явное несоответствие между установленным судом 


\section{ЧЕЛОВЕК И СОВРЕМЕННОЕ ОБЩЕСТВО В СОЦИАЛЬНОМ, ПРАВОВОМ, ЭКОНОМИЧЕСКОМ РАКУРСАХ}

характером нравственных и физических страданий и присужденной ко взысканию суммой компенсации является основанием для отмены решения.

Изменение судом апелляционной инстанции размера определенной судом первой инстанции суммы компенсации морального вреда возможно только при наличии оснований (неправильное определение обстоятельств, имеющих значение для дела; недоказанность установленных судом первой инстанции обстоятельств, имеющих значение для дела; несоответствие выводов суда первой инстанции, изложенных в решении суда, обстоятельствам дела и нарушение или неправильное применение норм материального права или норм процессуального права), предусмотренных ст. 330 ГПК РФ.

Так, например, Г. обратилась в суд с иском к организации о взыскании компенсации морального вреда, ссылаясь на то, что в результате произошедшего на производстве ответчика несчастного случая погиб ее сын, что причинило истцу глубокие нравственные страдания. Решением районного суда заявленные требования частично удовлетворены. Судом постановлено взыскать с ответчика в пользу Г. компенсацию морального вреда. Апелляционным определением данное решение изменено, в результате чего размер компенсации морального вреда, подлежащего взысканию в пользу Г., снижен. Судебная коллегия по гражданским делам Верховного Суда РФ, обсудив доводы кассационной жалобы Г., отменила состоявшееся по делу апелляционное определение, указав следующее: судом установлено, что сын истца, проходивший стажировку у ответчика, погиб вследствие нарушения технологического процесса. Указанное происшествие признано несчастным случаем на производстве. В соответствии с коллективным договором организации отцу погибшего предприятие выплатило компенсацию морального вреда, а также материальную помощь и помощь на погребение. Разрешая вопрос о размере компенсации морального вреда, суд первой инстанции признал установленным факт причинения истцу морального вреда в виде физических и нравственных страданий. Определяя размер компенсации морального вреда, суд сослался на установленные фактические обстоятельства дела, а также на принцип разумности и справедливости, в связи, с чем взыскал в пользу Г. определенную сумму. Изменяя вышеуказанное решение, суд второй инстанции указал на то, что размер компенсации морального вреда определен судом неверно, без учета фактических обстоятельств дела, при этом судебная коллегия указала, что в пользу отца, погибшего предприятием добровольно 


\section{ЧЕЛОВЕК И СОВРЕМЕННОЕ ОБЩЕСТВО В СОЦИАЛЬНОМ, ПРАВОВОМ, ЭКОНОМИЧЕСКОМ РАКУРСАХ}

выплачены суммы компенсации морального вреда и материальной помощи, в связи с чем значительно снизила размер взыскиваемой суммы [2, с.10].

Как отмечалось, основания для отмены или изменения решения суда первой инстанции в апелляционном порядке определены в ст. 330 ГПК РФ, однако в обжалуемом апелляционном определении не приведено указаний на то, какие конкретно нарушения норм материального или процессуального права допущены судом первой инстанции при разрешении вопроса о размере компенсации морального вреда, подлежащего взысканию в пользу Г. Значительно уменьшив размер компенсации морального вреда, взысканной судом первой инстанции, суд апелляционной инстанции не привел никаких обоснований снижения размера компенсации морального вреда, причиненного истцу смертью сына, сославшись на те же фактические обстоятельства по данному делу.

Указание суда апелляционной инстанции на добровольную выплату отцу погибшего компенсации морального вреда и материальной помощи не могло повлиять на право Г., как матери погибшего, на самостоятельное получение указанного возмещения вреда. Апелляционная инстанция также не приняла во внимание то обстоятельство, что брак между супругами Г. был расторгнут, кроме того, истец является пенсионером, в связи с чем она рассчитывала на помощь и поддержку сына. Смерть сына является для истца невосполнимой утратой, в результате чего она испытывала и продолжает испытывать глубокие физические и нравственные страдания. Эти обстоятельства были учтены судом первой инстанции при вынесении указанного решения и не были опровергнуты судом апелляционной инстанции [2, с.10].

Таким образом, каких-либо новых обстоятельств, позволяющих снизить определенную судом первой инстанции сумму компенсации морального вреда, судом апелляционной инстанции установлено не было, других доводов в обоснование значительного снижения, установленного судом первой инстанции размера компенсации морального вреда мотивировочная часть апелляционного определения не содержала, в связи, с чем правовых оснований для изменения решения суда первой инстанции в данном случае не имелось.

Основываясь на тщательном и доскональном изучении конкретных обстоятельств дела и рассмотрев степень страдания потерпевшего (по его собственным оценкам, по мнению его родных и близких, психолога и 


\section{ЧЕЛОВЕК И СОВРЕМЕННОЕ ОБЩЕСТВО В СОЦИАЛЬНОМ, ПРАВОВОМ, ЭКОНОМИЧЕСКОМ РАКУРСАХ}

заключению судебно-психологической экспертизы), суд может прийти к выводу о размере присуждаемой компенсации.

Итак, проблема определения размера возмещения в денежной форме, вызывает большие затруднения в судах. Статья 195 ГПК РФ, обязывающая суд к вынесению законных и обоснованных решений, не содержит каких-либо изъятий. Отсюда следует, что и в части размера возмещения морального вреда в денежной форме решение также должно быть законным и обоснованным. Для того чтобы обеспечить выполнение этого требования, ст. 198 ГПК РФ устанавливает, что в мотивировочной части решения суда должны быть указаны обстоятельства дела, установленные судом, доказательства, на которых основаны выводы суда, и доводы, по которым он отвергает те или иные обстоятельства. Ответственность за причинение морального вреда имеет явно выраженный компенсационный характер.

При возмещении имущественного вреда гражданское законодательство применяет принцип эквивалентности размера возмещения размеру причиненного вреда. В случае компенсации морального вреда принцип эквивалентности неприменим в силу особой специфики. Поскольку вред причинен и должен быть компенсирован, из смысла гражданского законодательства вытекает, что к компенсации морального вреда может и должен применяться принцип более низкого уровня - принцип адекватности (соответствия).

Судебная практика выявила определенные проблемы при принятии решения судами о размере компенсации морального вреда. В целом подходы к определению компенсации морального вреда не отработаны, в результате чего имеется значительный разброс и необоснованная произвольность в оценке судами размеров компенсации морального вреда. Полагаем, что необходимо разработать для всех судов базисный уровень размера компенсации морального вреда и методику определения ее окончательного размера.

\section{2. Компенсация морального вреда при причинении имущественного ущерба}

По общему правилу, имущественный ущерб не предполагает возможным компенсацию морального вреда, связанного с утратой или повреждением имущества, как бы не были сильны переживания по этому поводу у собственника. Вместе с тем, выход из сложившейся ситуации все же имеется, по крайней мере, такая возможность не исключается. 


\section{ЧЕЛОВЕК И СОВРЕМЕННОЕ ОБЩЕСТВО В СОЦИАЛЬНОМ, ПРАВОВОМ, ЭКОНОМИЧЕСКОМ РАКУРСАХ}

Статья 150 ГК РФ ориентирует нас на признание нематериальными благами тех прав и свобод, которые тесно связаны с личностью, хотя бы и имеют своим объектом конкретное имущество, как это, например, наглядно демонстрирует право на неприкосновенность жилища. Большинство таких прав имеют прямое закрепление в Конституции РФ в качестве фундаментальных свобод. Таким образом, если гражданину причинен моральный вред физические или нравственные страдания действиями, нарушающими его личные неимущественные права либо посягающими на принадлежащие гражданину нематериальные блага, а также в других случаях, предусмотренных законом, суд может возложить на нарушителя обязанность денежной компенсации указанного вреда.

Отметим, что формулировка ст. 35 Конституции РФ провозглашает охрану собственности законом и указывает на невозможность принудительного лишения человека, принадлежащего ему имущества, однако содержательно перед нами вполне конкретная норма, несущая имущественный характер. Неприкосновенность права собственности в Конституции РФ не провозглашена. Вместе с тем, согласно ст. 17 Конституции РФ гражданам гарантируется признание и защита прав, предусмотренных нормами международного права. Тем интереснее для нас содержание ст. 1 протокола № 1 Европейской конвенции о защите прав и основных свобод, провозглашающее право на уважение собственности.

Вероятно, этим объясняется одно из известных судебной практике в силу прямого указания закона исключение из общего правила, предусмотренное в ст. 15 Закона о защите прав потребителей [3, с.46]. Эта норма дает потребителю право независимо от возмещения имущественного вреда и понесенных потребителем убытков требовать компенсации морального вреда вследствие нарушения изготовителем (исполнителем, продавцом, уполномоченной организацией или уполномоченным индивидуальным предпринимателем, импортером) прав потребителя, предусмотренных законами [4, с.96].

В теории гражданского права дискуссионным является вопрос о том, обязан ли потерпевший доказывать и какими средствами тот факт, что он испытывал физические и нравственные страдания при нарушении его прав. В п. 45 Постановления Пленума Верховного Суда РФ от 28.06.2012 № 17 «О рассмотрении судами гражданских дел по спорам о защите права потребителей» (далее - Постановления от 28.06.2012 № 17) предлагается 


\section{ЧЕЛОВЕК И СОВРЕМЕННОЕ ОБЩЕСТВО В СОЦИАЛЬНОМ, ПРАВОВОМ, ЭКОНОМИЧЕСКОМ РАКУРСАХ}

исходить из того, что достаточным условием для удовлетворения иска потребителя о компенсации морального вреда является установленный судом факт нарушения прав потребителя (как имущественных, так и неимущественных). Иными словами, презюмируется, что потребитель при нарушении его прав всегда испытывает моральные страдания.

Анализ судебной практики по спорам о защите прав потребителей свидетельствует о том, что суды определяют размер компенсации морального вреда с учетом следующих обстоятельств: характер и социальная важность нарушенного права (блага) потребителя - жизнь и здоровье, право на жилище, право на удовлетворение духовных потребностей и т.д.; продолжительность неудобств, которые испытывал потребитель; отношение исполнителя к сложившейся ситуации - его готовность удовлетворить законные требования потребителя, включая рассмотрение претензии потребителя и проведение экспертизы качества работ (услуг) и материальное положение причинителя морального вреда [1, с.9].

Согласно ст. 15 Закона о защите прав потребителей моральный вред, причиненный потребителю вследствие нарушения изготовителем (исполнителем, продавцом, уполномоченной организацией или уполномоченным индивидуальным предпринимателем, импортером) прав потребителя, предусмотренных законами и правовыми актами РФ, регулирующими отношения в области защиты прав потребителей, подлежит компенсации причинителем вреда при наличии его вины. Размер компенсации морального вреда определяется судом и не зависит от размера возмещения имущественного вреда, она осуществляется независимо от возмещения имущественного вреда и понесенных потребителем убытков. При решении судом вопроса о компенсации потребителю морального вреда достаточным условием для удовлетворения иска является установленный факт нарушения прав потребителя. Поскольку размер компенсации морального вреда определяется судом независимо от размера возмещения имущественного вреда, ее размер не может быть поставлен в зависимость от стоимости товара (работы, услуги) или суммы подлежащей взысканию неустойки.

Нетрудно видеть, что в п. 45 Постановления от 28.06.2012 N 17 фактически устанавливается презумпция причинения потребителю морального вреда в случае нарушения его прав, т.е. не усматривается никаких препятствий 


\section{ЧЕЛОВЕК И СОВРЕМЕННОЕ ОБЩЕСТВО В СОЦИАЛЬНОМ, ПРАВОВОМ, ЭКОНОМИЧЕСКОМ РАКУРСАХ}

для того, чтобы не применять отмеченную презумпцию во всех случаях, когда закон допускает компенсацию морального вреда.

Однако то, что достаточным условием для удовлетворения иска является установленный факт нарушения прав потребителя, не означает, что суды не должны оценивать характер и степень причиненных потребителю страданий. В каждом конкретном случае должен определяться судом с учетом характера причиненных потребителю нравственных и физических страданий исходя из принципа разумности и справедливости.

Может ли это расцениваться как основание для отказа в удовлетворении требования о компенсации морального вреда. С точки зрения логики п. 45 Постановления от 28.06.2012 N 17 ответ на этот вопрос должен быть отрицательным, поскольку доказанность факта нарушения прав потребителя одновременно доказывает факт причинения ему морального вреда. Однако суд не сможет в этом случае определить размер компенсации с соблюдением требований ст. 151, 1101 ГК РФ. В подобной ситуации представлялось бы правильным присуждение компенсации морального вреда в символическом размере, например, 1 руб. Компенсация в таком размере фактически будет лишена своего имущественного и, следовательно, компенсационного в точном смысле слова значения, но судебным решением будет подтверждено наличие у потерпевшего самого права на компенсацию морального вреда [1, с. 21].

Другим таким исключением является презумпция причинения морального вреда при совершении должностными лицами органов власти незаконных действий, чему посвящены ст. 1069, 1070 ГК РФ.

Между тем указанные примеры скорее являются средством достижения баланса частных и публичных интересов, поскольку потребитель или обращающийся к чиновнику, заранее является слабой стороной в возникающих отношениях.

Как же быть, если имущественные потери понесены в связи с поведением соседа или стороны по договору, какой является такой же обычный гражданин, или если договор не является потребительским по своим свойствам?

Довольно часто, хотя и не всегда, действия иных лиц, причиняющие имущественный ущерб собственнику, могут быть квалифицированы как преступление. При определенных условиях, когда правоохранительные органы отказывают в возбуждении уголовного дела, в соответствующем постановлении обычно содержится ссылка на ч. 2 ст. 14 УК РФ о том, что подтвержденное 


\section{ЧЕЛОВЕК И СОВРЕМЕННОЕ ОБЩЕСТВО В СОЦИАЛЬНОМ, ПРАВОВОМ, ЭКОНОМИЧЕСКОМ РАКУРСАХ}

материалами проверки деяние лица не образует состав уголовного преступления, поскольку лишь формально содержит признаки последнего.

Отказ в возбуждении уголовного дела в порядке п. 2 ч. 1 ст. 24 УПК РФ за отсутствием в действиях лица состава преступления на стадии проверки сообщения о преступлении соответствует закону, что было подтверждено Определением Конституционного Суда РФ от 07.02.2013 г. № 128-О, поскольку такое решение не зависит от волеизъявления потерпевшего - оно предопределяется исключительно общественными интересами, конкретизируемыми на основе требований закона и фактических обстоятельств дела.

Однако это дает поводов заявить о том, что в результате имеющихся объективных оснований, как правило, связанных с незначительностью материального ущерба для целей уголовного преследования, тем не менее было нарушено право на уважение собственности, - то нематериальное благо, гарантии которого установлены международным правом. Тем более, что сам факт противоправного поведения стороны нашел подтверждение, и лишь по формальным соображениям «не дотянул» до квалификации его как уголовного преступления. Такой подход к определению оснований компенсации морального вреда при понесенном материальном ущербе представляет значительный интерес и требует своего дальнейшего изучения.

Новая редакция ст. 151 ГК РФ устраняет какие-либо сомнения в том, что такой способ защиты гражданских прав, как компенсация морального вреда, может применяться лишь в отношении физического, а не юридического лица. Такой же вывод следует и из п. 11 ст. 152 ГК РФ в ее новой редакции, где установлено, что правила этой статьи о защите деловой репутации гражданина, за исключением положений о компенсации морального вреда, соответственно применяются к защите деловой репутации юридического лица. Собственно говоря, сомнения по этому поводу мало у кого возникали и раньше. Не было их, в частности, и у Конституционного Суда РФ, что следует из его Определения от 04.12.2003 г. № 508-О.

Однако Пленум Верховного Суда РФ неоднократно указывал на применимость норм о компенсации морального вреда к юридическим лицам - в п. 5 Постановления от 20.12.1994 г. № 10 и в п. 15 Постановления от 24.02.2005 г. № 3 .

Человек представляет интерес для других теми качествами, которыми он обладает, степенью выполнения им общественного долга. Чем сильнее развито 


\section{ЧЕЛОВЕК И СОВРЕМЕННОЕ ОБЩЕСТВО В СОЦИАЛЬНОМ, ПРАВОВОМ, ЭКОНОМИЧЕСКОМ РАКУРСАХ}

в человеке чувство уважения к другим людям, доброжелательность, благородство, отзывчивость, иные положительные свойства характера, тем большую ценность он имеет для общества, тем более высокую оценку он получает с помощью таких этических категорий, как честь, достоинство, деловая репутация. Распространить порочащие сведения - значит сообщить их широкой аудитории, нескольким или хотя бы одному человеку. Сообщение может быть публичным или приватным, произведено в письменной или устной форме, с использованием средств массовой информации, а также путем изображения (рисунок, фотомонтаж). Сообщение сведений, порочащих честь, достоинство и деловую репутацию, самому лицу, к которому они относятся, распространением не признается.

Под честью понимается определенная положительная социальная оценка человека или отражение его достоинства в сознании других людей. В один ряд с честью и достоинством гражданина поставлена деловая репутация. Деловая репутация складывается в процессе профессиональной, производственной, посреднической, торговой и иной деятельности гражданина или юридического лица. Гражданин вправе требовать по суду опровержения порочащих его честь, достоинство или деловую репутацию сведений, если распространивший такие сведения не докажет, что они соответствуют действительности. Опровержение должно быть сделано тем же способом, которым были распространены сведения о гражданине, или другим аналогичным способом.

Важно отметить что, если установить лицо, распространившее сведения, порочащие честь, достоинство или деловую репутацию гражданина, невозможно, гражданин, в отношении которого такие сведения распространены, вправе обратиться в суд с заявлением о признании распространенных сведений не соответствующими действительности.

Срок исковой давности по требованиям, предъявляемым в связи с распространением указанных сведений в средствах массовой информации, составляет один год со дня опубликования таких сведений в соответствующих средствах массовой информации.

Правила статьи 152 ГК РФ о защите деловой репутации гражданина, за исключением положений о компенсации морального вреда, соответственно применяются к защите деловой репутации юридического лица. Определяя размер компенсации морального вреда при защите деловой репутации суд должен учесть характер и содержание высказываний, степень распространения 


\section{ЧЕЛОВЕК И СОВРЕМЕННОЕ ОБЩЕСТВО В СОЦИАЛЬНОМ, ПРАВОВОМ, ЭКОНОМИЧЕСКОМ РАКУРСАХ}

недостоверных сведений, соразмерность заявленной компенсации причиненному вреду.

Под деловой репутацией принято понимать сложившиеся общественное мнение о профессиональных достоинствах и недостатках лица. Деловая репутация представляет собой своего рода доброе имя и учитывается в составе его нематериальных активов наряду с авторскими правами, ноу-хау и торговыми марками. Положительная деловая репутация связана с позитивным отношением контрагентов к ее обладателю, с доверием к нему и уверенностью в положительном результате сотрудничества. Отрицательная деловая репутация показывает нестабильность положения ее обладателя в экономическом обороте, недоверие к нему со стороны контрагентов. При этом в современном мире при ведении бизнеса важна его экологическая составляющая, а также соблюдение интересов граждан, в связи, с чем оспариваемые сведения носят порочащий характер [2, с.18].

Пленум Верховного Суда РФ в Постановлении от 20.12.1994 г. №10, разрешил такую коллизию в пользу специальной нормы, разъяснив, что опороченное юридическое лицо имеет право на такую компенсацию. Иную позицию занял Высший Арбитражный Суд РФ, резонно рассудив, что юридическое лицо в отличие от физического страданий претерпевать не может. Долгое время из-за отсутствия в АПК РФ нормы, позволяющей арбитражам рассматривать споры о защите деловой репутации с участием юридических лиц, общегражданские суды свободно брались за подобные дела, присуждая компенсации за моральный вред, причиненный такому истцу; в то время как арбитражные суды занимали прямо противоположную позицию, по которой юридическое лицо в силу своей природы не может страдать и получать моральные травмы.

В настоящее время, с учетом возросшего количества обращений в суды, как граждан, так и организаций, юристы столкнулись с неопределенностью в вопросе о том, как следует применять нормы, защищающие нематериальные блага юридических лиц [1, с.22]. Долгое время вплоть до 2003 г. из-за отсутствия в АПК РФ нормы, позволяющей арбитражам рассматривать споры о защите деловой репутации с участием юридических лиц, общегражданские суды свободно брались за подобные дела, присуждая компенсации за моральный вред, причиненный такому истцу; в то время как арбитражные суды 


\section{ЧЕЛОВЕК И СОВРЕМЕННОЕ ОБЩЕСТВО В СОЦИАЛЬНОМ, ПРАВОВОМ, ЭКОНОМИЧЕСКОМ РАКУРСАХ}

занимали прямо противоположную позицию, по которой юридическое лицо в силу своей природы не может страдать и получать моральные травмы.

Одно из подобных дел дошло до Конституционного Суда РФ, который отказал в удовлетворении жалобы заявителя В.А. Шлафмана, признав за юридическим лицом право получить компенсацию не только за убытки (в смысле статьи 15 ГК РФ), но и за нематериальные убытки. Свое решение Конституционный Суд РФ обосновал решением Европейского Суда по правам человека по делу «Комингерсол С.А. против Португалии» [1, с.17].

Кроме того, существует проблема ограничения свободы слова в целях защиты чести, достоинства и деловой репутации граждан и юридических лиц.

На сегодняшний день глава 59 ГК РФ не определяет механизм компенсации и не содержит норм, предусматривающих основания и правила взыскания «нематериальных убытков».

Невосполненный правовой пробел не позволяет сформировать механизм преследования СМИ и журналистов со стороны тех, кто пытается отсудить у них материальную компенсацию понесенных репутационных потерь.

Отсутствие прямого указания в законе на способ защиты деловой репутации юридических лиц не лишает их права предъявлять требования о компенсации убытков, в том числе нематериальных, причиненных умалением деловой репутации, или нематериального вреда, имеющего свое собственное содержание (отличное от содержания морального вреда, причиненного гражданину), которое вытекает из существа нарушенного нематериального права и характера последствий этого нарушения. Данный вывод основан на положении статьи 45 Конституции РФ, в соответствии с которой каждый вправе защищать свои права и свободы всеми способами, не запрещенными законом.

В Постановлении Конституционного Суда РФ от 30.10.2003г. № 15-П установлены требования к национальному закону: чтобы исключить возможность несоразмерного ограничения прав и свобод человека и гражданина в конкретной правоприменительной ситуации, норма должна быть формально определенной, точной, четкой и ясной, не допускающей расширительного толкования установленных ограничений и, следовательно, произвольного их применения.

Аналогичная позиция содержится и в Постановлении Конституционного Суда РФ от 11.11.2003 г. № 16-П: общеправовой критерий определенности, 


\section{ЧЕЛОВЕК И СОВРЕМЕННОЕ ОБЩЕСТВО В СОЦИАЛЬНОМ, ПРАВОВОМ, ЭКОНОМИЧЕСКОМ РАКУРСАХ}

ясности, недвусмысленности правовой нормы вытекает из конституционного принципа равенства всех перед законом и судом (ст. 19 Конституции РФ), поскольку такое равенство может быть обеспечено лишь при условии единообразного понимания и толкования правовой нормы всеми правоприменителями. Неопределенность содержания правовой нормы, напротив, допускает возможность неограниченного усмотрения в процессе правоприменения и ведет к произволу, а значит - к нарушению принципов равенства, а также верховенства закона.

В Постановлении Пленума ВС РФ № 3 указано на то, что право граждан на защиту чести, достоинства и деловой репутации является их конституционным правом, а деловая репутация юридических лиц - одним из условий их успешной деятельности. Поэтому суд, применяя данную норму, обязан учитывать те соответствующие ГК РФ положения, которые определяют суть и смысл существования юридического лица, по своей природе значительно отличающегося от физического лица.

Однако подобная ситуация вовсе не означает полной беззащитности органов внутренних дел перед прессой и общественностью. Методы и формы привлечения к ответственности за распространение ложной информации и сведений порочащего характера определены и в российском праве, и в прецедентах Европейского суда. По рекомендациям последнего, при причинении нематериального вреда следует руководствоваться принципом соблюдения баланса между правом на репутацию и правом на свободу слова и, соответственно, при причинении нематериального вреда возмещение производить также в нематериальной форме. Например, Европейский Суд считает уже достаточным одного признания судом сведений ложными и порочащими репутацию. Другим способом нематериальной, но весьма эффективной компенсации служит обязательство ответчика опровергнуть распространенные сведения.

При очевидной неэффективности схемы разорения «неугодного» издания путем предъявления денежных исков, откровенно противоречащей принципам свободы слова и позиции Европейского суда, более важным инструментом может стать именно путь нематериальных взысканий. При этом очевидно, что неоднократное опровержение собственных материалов, повторяющиеся извинения, публикация решений суда неизбежно приведут к тому, что издание 


\section{ЧЕЛОВЕК И СОВРЕМЕННОЕ ОБЩЕСТВО В СОЦИАЛЬНОМ, ПРАВОВОМ, ЭКОНОМИЧЕСКОМ РАКУРСАХ}

перейдет в разряд «заказных», что нанесет более ощутимый удар по его репутации и авторитету среди читателей.

Например, В 2011 году УВД по Вологодской области было подано 6 исков к СМИ о защите деловой репутации и взыскании денежной компенсации морального вреда. 4 иска были удовлетворены. Суд признал сведения, распространенные СМИ, не соответствующими действительности и порочащими деловую репутацию УВД. Кроме того, суд обязал ответчиков опубликовать опровержение указанных сведений и взыскал в пользу УВД по Вологодской области денежную компенсацию морального вреда на общую сумму 300000 рублей. Поскольку некоторые публикации содержали сведения, порочащие честь, достоинство и деловую репутацию начальника УВД по Вологодской области, им было подано три иска в защиту своих прав. Суд, признавая сведения, распространенные в отношении начальника УВД, не соответствующими действительности и порочащими его честь, достоинство и деловую репутацию, взыскал с ответчиков в пользу начальника УВД по Вологодской области 395000 рублей в качестве компенсации морального вреда $[1$, c.17].

Итак, можно выделить, что основными причинами возникновения вреда, причиненного юридическому лицу при защите деловой репутации являются отсутствие федерального закона, ограничивающего свободу слова порочащих деловую репутацию и обязательное предварительное обращение с таким требованием к ответчику.

По делам данной категории необходимо учитывать разъяснения, данные Пленумом Верховного Суда РФ в Постановлениях от 31.10 .1995 г. №8 «О некоторых вопросах применения судами Конституции РФ при осуществлении правосудия» и от 10.10.2003 г. №5 «О применении судами общей юрисдикции общепризнанных принципов и норм международного права и международных договоров Российской Федерации».

Полагаем, что в связи с существенным изменением статей 151,152 ГК РФ в области института морального вреда теперь следует ожидать внесения соответствующих изменений в Постановления Пленума Верховного Суда РФ от 20.12.1994 г. № 10 и от 24.02.2005 г. № 3.

Анализируя судебную практику некоторых зарубежных стран в рассматриваемой нами области компенсации морального вреда, обращает на себя внимание явно прослеживающаяся тенденция к упорядочению при 


\section{ЧЕЛОВЕК И СОВРЕМЕННОЕ ОБЩЕСТВО В СОЦИАЛЬНОМ, ПРАВОВОМ, ЭКОНОМИЧЕСКОМ РАКУРСАХ}

определении размеров компенсации, что достигается, например, в Англии путем введения таблиц для определения размеров компенсации морального вреда, причиненного умышленными преступлениями, а в Германии выработанным судебной практикой предписанием ориентироваться на ранее вынесенные судебные решения по делам, связанным с сопоставимыми правонарушениями. Ввиду казуистичности оснований ответственности за причинение морального вреда по неосторожности определение размера компенсации в англо-американском праве формально не упорядочено, что подвергается критике в правоведческой среде, но необходимость подчиняться прецедентам при разрешении вопроса о наличии оснований ответственности фактически приводит к тому, что судья принимает во внимание и размер компенсации морального вреда, присужденный ранее в сходном деле.

Иная ситуация складывается в отношении определения размера компенсации морального вреда в российской правоприменительной практике. Проблема отсутствия точно сформулированных критериев оценки размера компенсации морального вреда и общего метода количественной оценки размера компенсации порождает сложности.

Одним из способов решения рассмотренных проблем урегулирования споров компенсации морального вреда нам видится в расширении для граждан возможностей досудебного урегулирования споров с взысканием компенсации морального вреда за необоснованный и явный отказ в удовлетворении их законных требований, за несвоевременное удовлетворение таких требований, за отказ от рассмотрения или за несвоевременное рассмотрение обращения гражданина с такими требованиями.

Представляется, что для урегулирования взаимоотношений сторон на досудебной стадии урегулирования спора необходимо принятие отдельного федерального закона, основные концептуальные положения которого заключаются в следующем:

Во-первых, моральный вред, причиненный одной стороне гражданину в порядке досудебного урегулирования споров вследствие того, что другая сторона государственный (муниципальный) орган или его должностные лица либо индивидуальный предприниматель или юридическое лицо (субъект), обязанная выполнить явно законные требования гражданина, отказывается это сделать или делает это несвоевременно либо субъект отказывается от рассмотрения или несвоевременно рассматривает обращение гражданина, 


\section{ЧЕЛОВЕК И СОВРЕМЕННОЕ ОБЩЕСТВО В СОЦИАЛЬНОМ, ПРАВОВОМ, ЭКОНОМИЧЕСКОМ РАКУРСАХ}

содержащее явно законные требования к субъекту, подлежит компенсации в повышенном размере причинителем вреда (субъектом) при наличии его вины, установленной судом.

Полагаем, что повышенный размер компенсации морального вреда должен быть значительным в денежном выражении, поскольку компенсирует страдания граждан по поводу очевидного и грубого нарушения их прав и законных интересов. Повышенный размер компенсации морального вреда должен быть кратным минимальному размеру оплаты труда в РФ на день принятия судебного решения (независимо от цены иска) по гражданским делам, по которым в порядке досудебного урегулирования споров гражданину было отказано в удовлетворении его явно законных требований; верхнего предела повышенного размера компенсации морального вреда не устанавливается.

Во-вторых, при удовлетворении судом иска в пользу гражданина по требованиям, явно предусмотренным законом, суд взыскивает с другой стороны (субъекта) за несоблюдение в досудебном добровольном порядке удовлетворения требований гражданина штраф в пятикратном размере от суммы, присужденной судом в пользу гражданина, а за несвоевременное добровольное удовлетворение вышеуказанных требований - штраф в трехкратном размере от суммы, присужденной судом в пользу гражданина. Значение таких штрафов состоит в том, чтобы наказать за грубейшее нарушение очевидных прав гражданина и предупредить такие нарушения в дальнейшем.

В-третьих, отказ субъекта от рассмотрения или несвоевременное рассмотрение на досудебной стадии обращения гражданина, содержащего явно законные требования к субъекту, также влекут за собой право гражданина в судебном порядке взыскать повышенный размер (сумму) компенсации морального вреда, кроме того, субъект (ответчик по делу) судом будет соответствующим образом оштрафован.

В-четвертых, сторона - истец гражданин освобождается от уплаты государственной пошлины при обращении в суд.

Таким образом, работает принцип если в досудебном порядке добровольно в установленные сроки не удовлетворишь явно законные требования гражданина либо откажешься рассматривать такое обращение гражданина, то после судебного решения будешь платить во много раз больше. Поэтому права граждан с помощью досудебного урегулирования споров будут 


\section{ЧЕЛОВЕК И СОВРЕМЕННОЕ ОБЩЕСТВО В СОЦИАЛЬНОМ, ПРАВОВОМ, ЭКОНОМИЧЕСКОМ РАКУРСАХ}

эффективно защищены большей компенсацией, что будет способствовать добровольному и скорейшему удовлетворению очевидно законных требований граждан к государственным (муниципальным) органам или их должностным лицам либо к индивидуальным предпринимателям или к юридическим лицам, с которыми граждане ежедневно вступают в те или иные правоотношения [1, c.6]. При этом вышеуказанный закон, с одной стороны, будет защищать граждан от грубого и очевидного нарушения их прав и законных интересов, а с другой стороны - снизит количество обращений в суды.

Федеральный закон по обозначенной проблематике должен содержать следующее:

предмет регулирования (отношения между гражданином, с одной стороны, и государственным (муниципальным) органом либо их должностными лицами или индивидуальным предпринимателем, или юридическим лицом - с другой стороны (субъект), возникающие в ходе досудебного урегулирования споров и влекущие в дальнейшем - в судебном порядке - повышенный размер (сумму) компенсации морального вреда и взыскание соответствующего штрафа);

\section{сфера действия.}

Федеральный закон будет применяться, если одна сторона (субъект), обязанная выполнить явно законные требования другой стороны гражданин, отказывается это сделать или делает это несвоевременно на досудебной стадии, то по результатам судебного разбирательства у стороны-истца гражданина.

Кроме того, федеральный закон применяется, когда субъект отказывается от рассмотрения обращения гражданина, содержащего очевидно законные требования к субъекту, в порядке досудебного урегулирования споров; когда имеются несвоевременное рассмотрение субъектом обращения гражданина, содержащего очевидно законные требования к субъекту, и последующий отказ субъекта в удовлетворении таких требований либо последующее удовлетворение этих требований в порядке досудебного урегулирования споров;

права и обязанности гражданина в ходе досудебного урегулирования споров;

права и обязанности субъекта или их должностные лица либо индивидуальный предприниматель или юридическое лицо, к которому гражданин обратился с целью досудебного урегулирования споров); 


\section{ЧЕЛОВЕК И СОВРЕМЕННОЕ ОБЩЕСТВО В СОЦИАЛЬНОМ, ПРАВОВОМ, ЭКОНОМИЧЕСКОМ РАКУРСАХ}

срок рассмотрения субъектом обращения гражданина в порядке досудебного урегулирования споров с предоставлением ответа в письменной или электронной форме;

компенсация морального вреда и ее «повышенный размер (сумма)».

Гражданин за защитой своих прав и законных интересов может обратиться к субъекту в порядке досудебного урегулирования споров, а затем в суд, либо обратиться в суд на общих основаниях без соблюдения порядка досудебного урегулирования споров.

Граждане, ранее воспользовавшиеся порядком досудебного урегулирования споров, а также иные истцы по искам, связанным с защитой прав таких граждан, освобождаются от уплаты государственной пошлины в соответствии с Налоговым кодексом РФ, для чего также необходимо будет внести соответствующие незначительные дополнения.

Анализ норм действующего гражданского законодательства РФ при определении размера компенсации морального вреда показывает, что учитывать в целях определения размера компенсации следует не все фактические обстоятельства, при которых был причинен моральный вред, а только заслуживающие внимания для определения размера компенсации. Их перечень дифференцируется в зависимости от вида неимущественных благ, затронутых правонарушением.

Законодателем установлен ряд критериев, которые должны учитываться судом при определении размера компенсации морального вреда: степень вины потерпевшего и степень вины причинителя и его имущественное положение, степень физических и нравственных страданий потерпевшего, связанных с индивидуальными особенностями лица, которому причинен вред и иные заслуживающие внимания обстоятельства, характер физических и нравственных страданий, который должен оцениваться с учетом фактических обстоятельств, при которых был причинен моральный вред, и индивидуальных особенностей потерпевшего и требования разумности и справедливости.

Поскольку законодатель отказался от нормативного установления базисного уровня и методики определения размера компенсации, таким образом, предоставил этот вопрос на усмотрение суда, то этим судом следует считать Верховный Суд РФ, который должен, в порядке обеспечения единообразного применения законов при осуществлении правосудия, предложить судам общий подход к определению размера компенсации 


\section{ЧЕЛОВЕК И СОВРЕМЕННОЕ ОБЩЕСТВО В СОЦИАЛЬНОМ, ПРАВОВОМ, ЭКОНОМИЧЕСКОМ РАКУРСАХ}

морального вреда, оставляя при этом достаточный простор усмотрению суда при решении конкретных дел[5, с.76].

Вероятно, могут быть предложены различные базисные уровни размера компенсации морального вреда и методы определения ее размера, поэтому представляется целесообразным использовать эти соотношения для определения соразмерности компенсаций презюмируемого морального вреда при нарушениях соответствующих прав.

Предлагаемый нами базисный уровень размера компенсации определяется применительно к страданиям, испытываемым потерпевшим при причинении тяжкого вреда здоровью, и составляет 720 минимальных размеров заработной платы (далее - МЗП), исходя из МЗП, установленного законодательством по состоянию на момент вынесения судом решения по делу. 720 МЗП - это заработок физического лица за 10 лет при размере месячного заработка 6 МЗП. Установление именно такого среднемесячного заработка физического лица в настоящее время в наибольшей степени стимулируется налоговым законодательством. Применение этого базисного уровня и упомянутых выше соотношении максимальных санкций норм уголовного кодекса позволяет разработать таблицу размеров компенсации презюмируемого морального вреда применительно к различным видам нарушений прав личности. Базисный размер компенсации и таблица будут подвергаться корректировке при соответствующих изменениях законодательства, если они дадут основания полагать, что иной размер компенсации будет более разумным.

В приводимой ниже таблице №1 показаны определенные на основе предлагаемого метода размеры компенсации презюмируемого морального вреда для различных видов правонарушений.

\section{Таблица 1}

Размеры компенсации презюмируемого морального вреда

\begin{tabular}{|l|c|c|}
\hline Вид правонарушения & \multicolumn{2}{|c|}{$\begin{array}{c}\text { Размер компенсации } \\
\text { презюмируемого } \\
\text { морального вреда }\end{array}$} \\
\hline & \multicolumn{2}{|c|}{ Относит.ед. МЗП } \\
\hline Причинение тяжкого вреда здоровью & 0,80 & 576 \\
\hline $\begin{array}{l}\text { То же, совершенное с особой жестокостью, издевательствами или } \\
\text { мучениями }\end{array}$ & 1,00 & 720 \\
\hline Причинение средней тяжести вреда здоровью & 0,30 & 216 \\
\hline
\end{tabular}




\section{ЧЕЛОВЕК И СОВРЕМЕННОЕ ОБЩЕСТВО В СОЦИАЛЬНОМ, ПРАВОВОМ, ЭКОНОМИЧЕСКОМ РАКУРСАХ}

\begin{tabular}{|c|c|c|}
\hline $\begin{array}{l}\text { То же, совершенное с особой жестокостью, издевательствами или } \\
\text { мучениями }\end{array}$ & 0,50 & 360 \\
\hline Причинение легкого вреда здоровью & 0,03 & 24 \\
\hline Нанесение побоев & 0,025 & 18 \\
\hline Истязание & 0,30 & 216 \\
\hline Угроза убийством или причинением тяжкого вреда здоровью & 0,20 & 144 \\
\hline $\begin{array}{l}\text { Принуждение к изъятию органов или тканей человека для } \\
\text { трансплантации }\end{array}$ & 0,40 & 288 \\
\hline То же, совершенное в отношении зависимого или беспомощного лица & 0,5 & 360 \\
\hline Заражение венерической болезнью & 0,05 & 36 \\
\hline Заражение ВИЧ-инфекцией & 0,50 & 360 \\
\hline $\begin{array}{l}\text { Неоказание помощи больному, повлекшее причинение средней тяжести } \\
\text { вреда здоровью больного }\end{array}$ & 0,03 & 24 \\
\hline То же, повлекшее причинение тяжкого вреда здоровью больного & 0,30 & 216 \\
\hline Похищение человека & 0,80 & 576 \\
\hline То же, с причинением физических страданий & 1,00 & 720 \\
\hline То же, повлекшее тяжкий или средней тяжести вред здоровью & 1,50 & 1080 \\
\hline Незаконное лишение свободы (за один день) & 0,30 & 216 \\
\hline То же, с причинением физических страданий & 0,50 & 360 \\
\hline То же, повлекшее тяжкий или средней тяжести вред здоровью & 0,80 & 576 \\
\hline Незаконное помещение в психиатрический стационар (за один день) & 0,30 & 216 \\
\hline То же, причинившее тяжкий или средней тяжести вред здоровью & 0,70 & 504 \\
\hline Распространение ложных порочащих сведений & 0,03 & 24 \\
\hline То же, в средстве массовой информации & 0,05 & 36 \\
\hline То же, соединенное с обвинением в совершении тяжкого преступления & 0,30 & 216 \\
\hline Оскорбление & 0,015 & 12 \\
\hline То же, в средстве массовой информации & 0,03 & 24 \\
\hline Половое сношение или иные насильственные & 0,60 & 432 \\
\hline \multicolumn{3}{|l|}{$\begin{array}{l}\text { действия сексуального характера с применением насилия, угроз или } \\
\text { использованием беспомощного состояния потерпевшего }\end{array}$} \\
\hline $\begin{array}{l}\text { То же, сопряженное с угрозой убийством или причинением тяжкого } \\
\text { вреда здоровью }\end{array}$ & 1,00 & 720 \\
\hline $\begin{array}{l}\text { То же, повлекшее тяжкий вред здоровью или заражение ВИЧ- } \\
\text { инфекцией }\end{array}$ & 1,50 & 1080 \\
\hline $\begin{array}{l}\text { Понуждение к действиям сексуального характера путем шантажа или } \\
\text { угро3 }\end{array}$ & 0,10 & 72 \\
\hline Дискриминация гражданина & 0,20 & 144 \\
\hline Нарушение неприкосновенности частной жизни & 0,03 & 24 \\
\hline $\begin{array}{l}\text { Нарушение тайны переписки, телефонных переговоров, почтовых или } \\
\text { иных сообщений }\end{array}$ & 0,03 & 24 \\
\hline Нарушение неприкосновенности жилища & 0,025 & 18 \\
\hline То же, с применением насилия или угроз & 0,20 & 144 \\
\hline Неправомерный отказ в предоставлении информации & 0,025 & 18 \\
\hline
\end{tabular}




\section{ЧЕЛОВЕК И СОВРЕМЕННОЕ ОБЩЕСТВО В СОЦИАЛЬНОМ, ПРАВОВОМ, ЭКОНОМИЧЕСКОМ РАКУРСАХ}

\begin{tabular}{|l|c|c|}
\hline \hline Воспрепятствование осуществлению избирательных прав & 0,03 & 24 \\
\hline Незаконный отказ в приеме на работу & 0,03 & 24 \\
\hline Незаконное увольнение & 0,1 & 72 \\
\hline Иное нарушение трудовых прав & 0,05 & 36 \\
\hline Нарушение неимущественных прав авторов и изобретателей & 0,20 & 144 \\
\hline Нарушение права на свободу совести и вероисповеданий & 0,025 & 18 \\
\hline Разглашение тайны усыновления и искусственного оплодотворения & 0,20 & 144 \\
\hline Подмена ребенка & 0,50 & 360 \\
\hline Нарушение имущественных прав потребителей & 0,05 & 36 \\
\hline То же, причинившее значительный ущерб & 0.20 & 144 \\
\hline Причинение смерти близкому родственнику & 0.30 & 216 \\
\hline То же, совершенное с особой жестокостью & 0,80 & 576 \\
\hline $\begin{array}{l}\text { Надругательство над телом или местом захоронения близкого } \\
\text { родственника }\end{array}$ & 0,025 & 18 \\
\hline Привлечение невиновного к уголовной ответственности & 0,50 & 360 \\
\hline То же, соединенное с обвинением в совершении тяжкого преступления & 1,00 & 720 \\
\hline Осуждение невиновного & 0,40 & 288 \\
\hline То же, повлекшее тяжкие последствия & 1,00 & 720 \\
\hline Незаконное задержание & 0,20 & 144 \\
\hline $\begin{array}{l}\text { Незаконное заключение под стражу или содержание под стражей (за } \\
\text { один день) }\end{array}$ & 0,04 & 28,8 \\
\hline Иное незаконное ограничение свободы (за один день) & 0,01 & 7,2 \\
\hline Принуждение к даче показаний & 0,30 & 216 \\
\hline То же, соединенное с применением насилия, издевательств или пытки & 0,80 & 576 \\
\hline $\begin{array}{l}\text { Иное ущемление прав и свобод гражданина неправомерными } \\
\text { деиствиями и решениями органов власти и управления }\end{array}$ \\
\hline То же, повлекшее существенный вред & 0,05 & 36 \\
\hline
\end{tabular}

При рассмотрении конкретного дела в результате учета вышеуказанных критериев, за исключением требований разумности и справедливости, которые оказываются заранее учтенными при применении этого метода, итоговый размер компенсации может как уменьшиться, так и увеличиться по сравнению с размером компенсации презюмируемого морального вреда, образуя, таким образом, размер компенсации действительного морального вреда. При этом, по нашему мнению, размер компенсации действительного морального вреда не должен превышать размер компенсации презюмируемого морального вреда более чем в четыре раза, что позволяет зафиксировать применительно к отдельным видам правонарушений максимальный уровень размера компенсации. 


\section{ЧЕЛОВЕК И СОВРЕМЕННОЕ ОБЩЕСТВО В СОЦИАЛЬНОМ, ПРАВОВОМ, ЭКОНОМИЧЕСКОМ РАКУРСАХ}

В сторону уменьшения размер компенсации действительного морального вреда может отклоняться от размера компенсации презюмируемого морального вреда неограниченно, вплоть до полного отказа в компенсации морального вреда. Такой подход представляется оправданным, так как он, с одной стороны, устанавливает определенные ориентиры и пределы для правоприменителя, оставляя вместе с тем достаточную свободу для судебного усмотрения и учета особенностей конкретного дела в установленных пределах, и, с другой стороны, учитывает, что человеческая психика имеет определенный «пороговый» уровень реагирования страданиями на негативные внешние воздействия, по превышении которого дальнейшего увеличения степени страданий не происходит.

Необходимо упомянуть еще два критерия оценки размера компенсации морального вреда - степень вины потерпевшего и имущественное положение гражданина - причинителя вреда (ст. 1083 ГК РФ). Степень вины потерпевшего при наличии в его действиях грубой неосторожности, содействовавшей возникновению или увеличению вреда, является обязательным критерием оценки судом размера компенсации морального вреда, в то время как имущественное положение гражданина - причинителя вреда - это факультативный критерий, его применение является не обязанностью суда, а его правом проявить снисхождение к причинителю вреда, приняв во внимание его имущественное положение при определении окончательного размера подлежащей выплате компенсации.

Для облегчения учета критериев компенсации морального вреда можно рекомендовать применение формулы, объединяющей их, для целей определения размера компенсации действительного морального вреда:

$\mathrm{K}=\mathrm{M} \times \mathrm{C} \times$ И $\mathrm{x}$,

где К - размер компенсации действительного морального вреда;

M - размер компенсации презюмируемого морального вреда (см. табл.1);

С - степень вины причинителя вреда: при наличии простой неосторожности - 0,25, при наличии грубой неосторожности - 0,5, при наличии косвенного умысла - 0,75 и 0,5 - при наличии прямого умысла.

И - коэффициент индивидуальных особенностей потерпевшего.

П - степень вины потерпевшего, при этом поскольку вина потерпевшего учитывается в целях снижения размера компенсации только при наличии в его действиях грубой неосторожности, ее значение можно принимать равным 0,5. 


\section{ЧЕЛОВЕК И СОВРЕМЕННОЕ ОБЩЕСТВО В СОЦИАЛЬНОМ, ПРАВОВОМ, ЭКОНОМИЧЕСКОМ РАКУРСАХ}

Эти допущения могут быть использованы, если суд не найдет оснований для применения иных значений этих критериев в установленных пределах. Степень вины потерпевшего П, при наличии любого вида умысла потерпевшего должна приниматься равной 1, что тождественно отказу в компенсации морального вреда (п. 1 ст. 1083 ГК РФ).

Как видно из приведенной формулы, максимальный размер компенсации действительного морального вреда равен четырехкратному размеру компенсации презюмируемого морального вреда.

Что касается критериев учета индивидуальных особенностей потерпевшего и заслуживающих внимания обстоятельств причинения морального вреда, то они проявляют наиболее сильную зависимость от вида правонарушения. Хотя некоторые из этих особенностей и обстоятельств являются общими для всех видов правонарушений (так, добровольная компенсация правонарушителем причиненного морального вреда или совершение им иных действий, направленных на сглаживание причиненных страданий, всегда должно влечь существенное снижение коэффициента учета фактических обстоятельств и, соответственно, размера компенсации действительного морального вреда), но, как правило, каждому виду правонарушений свойственны характерные именно для этого вида особенности и обстоятельства.

Например, при причинении тяжкого вреда здоровью, опасного для жизни потерпевшего, одним из заслуживающих внимания обстоятельств является характер телесного повреждения, поскольку в некоторых случаях физические и нравственные страдания потерпевшего могут быть незначительны. Так, например, повреждение крупного кровеносного сосуда при своевременно оказанной медицинской помощи может не повлечь существенных болевых ощущений, а нравственные страдания могут выразиться в кратковременных переживаниях в виде страха за свою жизнь, испытанного до устранения непосредственной угрозы жизни. Эти обстоятельства должны быть учтены судом путем установления коэффициента существенно меньшим единицы. В иных случаях может быть установлено, что у потерпевшего более низкий или высокий по сравнению с нормальным уровень болевых реакций, что явится для суда основанием для соответствующей корректировки размера компенсации действительного морального вреда путем установления коэффициента учета 


\section{ЧЕЛОВЕК И СОВРЕМЕННОЕ ОБЩЕСТВО В СОЦИАЛЬНОМ, ПРАВОВОМ, ЭКОНОМИЧЕСКОМ РАКУРСАХ}

индивидуальных особенностей и соответственно меньшим или большим единицы.

При определении размера компенсации морального вреда, причиненного правонарушениями, умаляющими честь и достоинство личности, обстоятельствами, влияющими на величину коэффициента, являются характер распространенных сведений, определяющий ту степень, в какой они могут признаваться позорящими; последствия, которые наступили для потерпевшего в результате распространения таких сведений (увольнение с работы, неизбрание на выборную должность, распад семьи и т. п.). Применение коэффициента индивидуальных особенностей и для этого вида правонарушений может быть основано на том, что субъективное восприятие одних и тех же сведений в качестве позорящих может зависеть от особенностей нравственных установок и склада характера потерпевшего.

В случае нарушения психической неприкосновенности личности в результате принуждения следователем или лицом, производящим дознание, подозреваемого, обвиняемого, потерпевшего или свидетеля к даче показаний путем применения угроз, шантажа или иных незаконных действий, для целей определения размера компенсации следует принимать во внимание характер угроз, возможную опасность для потерпевшего в случае их реализации, продолжительность и интенсивность применения угроз.

Таким образом, как видно из этих примеров, применительно к каждому виду правонарушений может быть определен свойственный этому виду круг индивидуальных особенностей потерпевшего и заслуживающих внимания обстоятельств, влияющих на оценку размера компенсации морального вреда.

Предложенные в настоящей главе возможные пути решения указанных проблем в области компенсации морального вреда, а именно обязательного досудебного урегулирования спора и утверждения методики определения компенсации морального вреда на законодательном уровне, позволят снизить объем поступающих в суды соответствующих требований потерпевших, а также облегчить работу судьям при разрешении таких споров. 


\section{Список литературы}

1. Бугаенко Н.В., Кратенко М.В. Судебная практика по гражданским делам. Споры о защите прав потребителей: Научно-практическое пособие // Юстицинформ, 2013.

2. Будылин С.Л. Штрафные убытки. Теперь и в России? // Вестник гражданского права, 2013, N 4.

3. Мицык Г.Ю. О строении системы субъектов отношений, регулируемых законодательством о защите прав потребителей //Экономика. Предпринимательство. Окружающая среда. 2013. Т. 1. № 53. С. 45-48.

4. Мицык Г.Ю. Система субъектов отношений, регулируемых законодательством о защите прав потребителей: дис. ... канд. юрид. наук. М., 2013. $190 \mathrm{c}$.

5. Мицык Г.Ю. Механизм взыскания судебных расходов //Вестник арбитражной практики. 2017. № 4 (71). С. 68-79.

(C) Г.Ю. Мицык, 2020 